\title{
Teaching Video NeuroImage: Papilledema and Cavernous Sinus Fistula Caused by Occipital Dural Arteriovenous Malformation in a Patient With Postoperative Laryngeal Cancer
}

Chaoyi Feng, MD, PhD, Qian Chen, MD, PhD, Weimin Chen, MD, Jianjun Tang, MD, PhD, Xinghuai Sun, MD, PhD, and Guohong Tian, MD, PhD

Neurology ${ }^{\circledR}$ 2021;97:e1751-e1752. doi:10.1212/WNL.0000000000012267

Figure Clinical and Imaging Findings

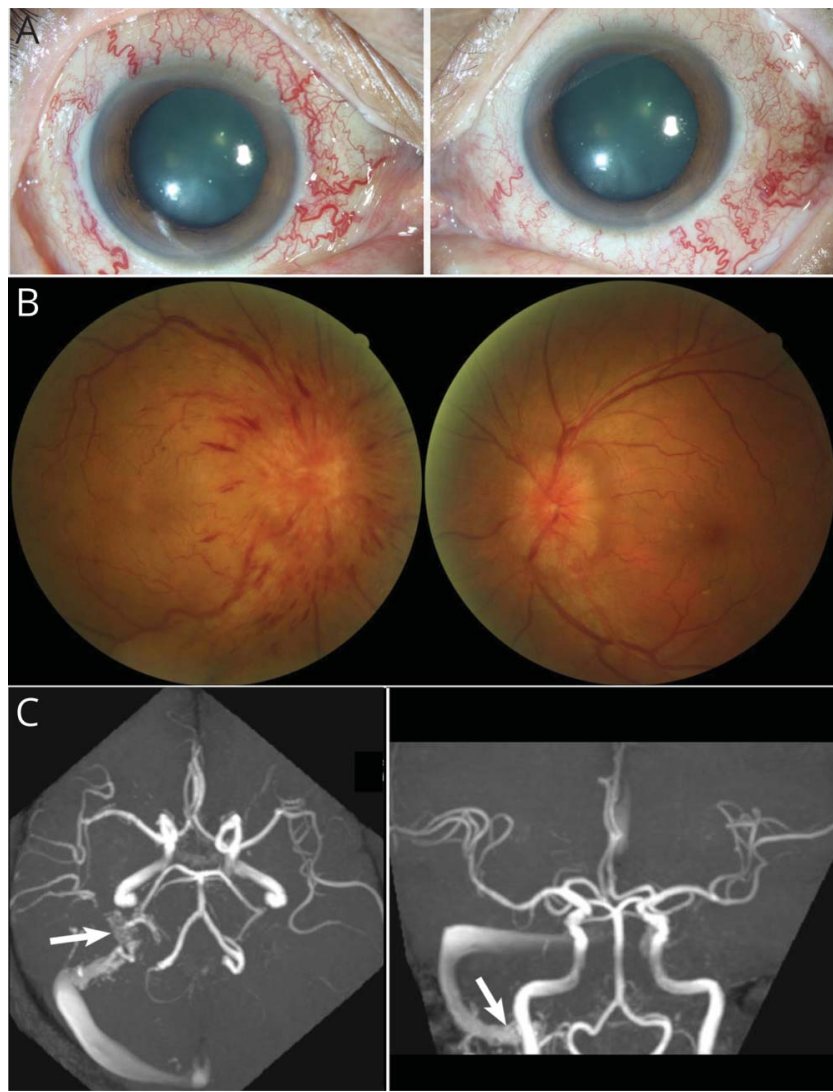

(A) Bilateral conjunctival corkscrew-shaped arterialized veins. (B) Bilateral papilledema, with severe peripapillary hemorrhage in the right eye due to the venous stasis. (C) Cerebral magnetic resonance angiography reveals abnormal vessels near right sigmoid sinus (arrows).

A 67-year-old man complained of red and bulging eyes for 3 months. He was diagnosed with laryngeal cancer and his bilateral internal jugular vein (IJV) was resected during the surgery. Ophthalmic examination revealed corkscrew-shaped arterialized conjunctival veins and severe bilateral papilledema. Magnetic resonance angiography revealed malformation vessels near the right sigmoid sinus (Figure). Cerebral digital subtraction angiography revealed an occipital dural arteriovenous malformation (AVM) near the right sigmoid sinus and venous drainage of

\section{Correspondence}

Dr. Tian

valentian99@hotmail.com

\section{MORE ONLINE}

Videos

Teaching slides

links.lww.com/WNL/

B435

From the Department of Ophthalmology (C.F., Q.C., X.S., G.T.), Eye and ENT Hospital, Fudan University; Department of Neurology (W.C., J.T.), Deji Hospital; and State Key Laboratory of Medical Neurobiology (X.S., G.T.), Institutes of Brain Science, Fudan University, Shanghai, China.

Go to Neurology.org/N for full disclosures. Funding information and disclosures deemed relevant by the authors, if any, are provided at the end of the article. 
the brain with a retrograde direction to cavernous sinus, superior/inferior ophthalmic vein, and finally external jugular vein, due to the resection of IJV (Video 1). After the embolization, most of the abnormal flow disappeared (Video 2), with partially improved papilledema on late follow-up. There is a very high probability that the formation of dural AVM is a complication of the neck dissection.

\section{Study Funding}

The authors were supported by grants from the State Key Program of National Science Foundation of China (82030027).

\section{Disclosure}

The authors report no disclosures relevant to the manuscript. Go to Neurology.org/N for full disclosures.

\begin{tabular}{lll}
\multicolumn{2}{l}{ Appendix } & Authors \\
\hline Name & Location & Contribution \\
\hline $\begin{array}{l}\text { Chaoyi } \\
\text { Feng, MD, } \\
\text { PhD }\end{array}$ & $\begin{array}{l}\text { Department of Ophthalmology, } \\
\text { Ef Fudan University, Shanghai, } \\
\text { China }\end{array}$ & $\begin{array}{l}\text { Major role in data } \\
\text { acquisition, analyzed the } \\
\text { ophthalmic examinations, } \\
\text { drafted the manuscript for } \\
\text { intellectual content }\end{array}$ \\
\hline $\begin{array}{l}\text { Qian } \\
\text { Chen, MD, } \\
\text { PhD }\end{array}$ & $\begin{array}{l}\text { Eepartment of Ophthalmology, } \\
\text { of Fudan University, Shanghai, } \\
\text { China }\end{array}$ & $\begin{array}{l}\text { Major role in data } \\
\text { acquisition, performed B } \\
\text { scan and other images }\end{array}$ \\
\hline
\end{tabular}

Appendix (continued)

\begin{tabular}{|c|c|c|}
\hline Name & Location & Contribution \\
\hline $\begin{array}{l}\text { Weimin } \\
\text { Chen, MD }\end{array}$ & $\begin{array}{l}\text { Department of Neurology, Deji } \\
\text { Hospital, Shanghai, China }\end{array}$ & $\begin{array}{l}\text { Major role in data } \\
\text { acquisition, diagnosis and } \\
\text { analyzed the data }\end{array}$ \\
\hline $\begin{array}{l}\text { Jianjun } \\
\text { Tang, MD, } \\
\text { PhD }\end{array}$ & $\begin{array}{l}\text { Department of Neurology, Deji } \\
\text { Hospital, Shanghai, China }\end{array}$ & $\begin{array}{l}\text { Major role in data } \\
\text { acquisition, digital } \\
\text { subtraction angiography } \\
\text { treatment }\end{array}$ \\
\hline $\begin{array}{l}\text { Xinghuai } \\
\text { Sun, MD, } \\
\text { PhD }\end{array}$ & $\begin{array}{l}\text { Department of } \\
\text { Ophthalmology, Eye Ear Nose } \\
\text { and Throat Hospital of Fudan } \\
\text { University; State Key } \\
\text { Laboratory of Medical } \\
\text { Neurobiology, Institutes of } \\
\text { Brain Science, Fudan } \\
\text { University, Shanghai, China }\end{array}$ & $\begin{array}{l}\text { Designed and } \\
\text { conceptualized the study, } \\
\text { grant support }\end{array}$ \\
\hline $\begin{array}{l}\text { Guohong } \\
\text { Tian, MD, } \\
\text { PhD }\end{array}$ & $\begin{array}{l}\text { Department of Ophthalmology, } \\
\text { Eye Ear Nose and Throat Hospital } \\
\text { of Fudan University; State Key } \\
\text { Laboratory of Medical } \\
\text { Neurobiology, Institutes of Brain } \\
\text { Science, Fudan University, } \\
\text { Shanghai, China }\end{array}$ & $\begin{array}{l}\text { Designed and } \\
\text { conceptualized the study, } \\
\text { major role in data } \\
\text { acquisition, interpreted } \\
\text { the data, drafted the } \\
\text { manuscript for intellectual } \\
\text { content }\end{array}$ \\
\hline
\end{tabular}

\section{References}

1. Buchanan TA, Harper DG, Hoyt WF. Bilateral proptosis, dilatation of conjunctival veins, and papilloedema: a neuro-ophthalmological syndrome caused by arteriovenous malformation of the torcular herophili. Br J Ophthalmol. 1982; 66(3):186-189.

2. Chaudhary N, Griauzde J, Gemmete JJ, et al. Issues in the diagnosis and management of the papilledema shunt. J Neuroophthalmol. 2014;34(3):259-263. 


\section{Neurology}

\section{Teaching Video NeuroImage: Papilledema and Cavernous Sinus Fistula Caused by Occipital Dural Arteriovenous Malformation in a Patient With Postoperative Laryngeal Cancer}

Chaoyi Feng, Qian Chen, Weimin Chen, et al. Neurology 2021;97;e1751-e1752 Published Online before print May 26, 2021 DOI 10.1212/WNL.0000000000012267

This information is current as of May 26, 2021

\section{Updated Information \& Services}

References

Subspecialty Collections

Permissions \& Licensing

Reprints including high resolution figures, can be found at: http://n.neurology.org/content/97/17/e1751.full

This article cites 2 articles, 1 of which you can access for free at: http://n.neurology.org/content/97/17/e1751.full\#ref-list-1

This article, along with others on similar topics, appears in the following collection(s):

Arteriovenous malformation

http://n.neurology.org/cgi/collection/arteriovenous_malformation Diplopia (double vision)

http://n.neurology.org/cgi/collection/diplopia_double_vision

Optic nerve

http://n.neurology.org/cgi/collection/optic_nerve

Orbit

http://n.neurology.org/cgi/collection/orbit

Visual loss

http://n.neurology.org/cgi/collection/visual_loss

Information about reproducing this article in parts (figures,tables) or in its entirety can be found online at:

http://www.neurology.org/about/about_the_journal\#permissions

Information about ordering reprints can be found online:

http://n.neurology.org/subscribers/advertise

Neurology ${ }^{\circledR}$ is the official journal of the American Academy of Neurology. Published continuously since 1951, it is now a weekly with 48 issues per year. Copyright @ 2021 American Academy of Neurology. All rights reserved. Print ISSN: 0028-3878. Online ISSN: 1526-632X.

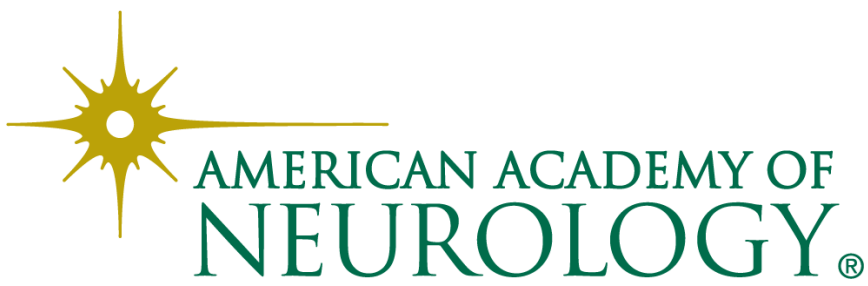

